\title{
Human Rights and the New Sustainable Mechanism of the Paris Agreement: A New Opportunity to Promote Climate Justice
}

\section{P Villavicencio Calzadilla*}

\section{P.E.R}

Pioneer in peer-reviewed, open access online law publications

Author

Paola Villavicencio Calzadilla

Affiliation

North-West University

South Africa

Email

p_villavicencio@hotmail.com

Date of submission

7 October 2017

Date published

26 January 2018

\section{Editor Prof C Rautenbach}

How to cite this article

Villavicencio Calzadilla P "Human Rights and the New Sustainable Mechanism of the Paris Agreement: A New Opportunity to Promote Climate Justice" PER / PELJ 2018(21) - DOI

http://dx.doi.org/10.17159/17273781/2018/v21i0a3189

Copyright

DOI

http://dx.doi.org/10.17159/1727-

3781/2018/v21i0a3189

\begin{abstract}
In the light of the new era of climate action under the Paris Agreement (PA) and the rights and justice issues raised by climate change-related policies and measures, this paper discusses the integration of a human rights component within the Sustainable Development Mechanism (SDM) of the PA. Established in article 6.4, the SDM is essentially a new mitigation mechanism available to all Parties aimed at helping them to achieve and increase their mitigation actions, while fostering sustainable development. Looking back at the experience of the Clean Development Mechanism (CDM) of the Kyoto Protocol, which bears great resemblance to the SDM, as well as to the human rights concerns raised during its implementation, the integration of human rights considerations into the SDM and its governing rules seems to be necessary to prevent negative outcomes and human rights harms when implemented. The adoption of such rules, consistent with international human rights, could provide an opportunity for State Parties to operationalise the language included in the PA and tackle the climate change challenge, while ensuring respect for human rights.
\end{abstract}

\section{Keywords}

Climate change; Paris Agreement; Human Rights; Clean Development Mechanism (CDM); Sustainable Development Mechanism (SDM). 


\section{Introduction}

Climate change has been identified as "probably the greatest human rights challenge of the $21^{\text {st }}$ century". ${ }^{1}$ The negative impacts of climate change, including melting glaciers, strong and more frequent storms, droughts and floods, and rising sea levels, affect millions of people worldwide and undermine the full enjoyment of a vast range of human rights, including the rights to life, food, health, water and sanitation, self-determination, development and housing. ${ }^{2}$ These impacts are felt most acutely by the poorest, disadvantaged and most marginalised people who, despite having contributed the least to climate change, are especially vulnerable and disproportionately affected by its effects. For them, dealing with climate change is simply a question of justice. ${ }^{3}$

However, human rights violations and climate injustices do not only arise by the direct or indirect effects of climate change; they can also emerge from actions to tackle climate change. Indeed, the Office of the High Commissioner for Human Rights (OHCHR) notes that

\section{... some of the climate change mitigation and adaptation efforts that have been employed to date have had counterproductive human rights impacts, particularly on the most marginalized. ${ }^{4}$}

Under international human rights law, States have the obligation to respect, protect and fulfil human rights. This threefold obligation consequently applies to all measures and policies undertaken by governments, as well as to issues under their control. In the context of climate change, these obligations apply not only to the level of ambition that States can agree to fight against climate change and protect human rights from its adverse impacts, but also to the mitigation and adaptation measures undertaken in response to it. Therefore, the human rights framework requires that efforts to mitigate and adapt to climate change be guided by relevant human rights norms and principles. By recognising that actions to combat climate change have also the potential to infringe human rights, as well as the need to

Paola Villavicencio Calzadilla. LLB (Universidad Salesiana de Bolivia) LLM PhD (Universitat Rovira i Virgili). Postdoctoral Fellow, Faculty of Law, North-West University, Potchefstroom, South Africa. Email: p_villavicencio@hotmail.com.

1 OHCHR 2015 http://www.ohchr.org/Documents/lssues/ClimateChange/COP21.pdf 6.

2 Report of the Special Rapporteur on the Issue of Human Rights Obligations Relating to the Enjoyment of a Safe, Clean, Healthy and Sustainable Environment UN Doc A/HRC/31/52 (2016) paras 23-32.

3 In this regard see, for example, Abate Climate Justice.

4 OHCHR 2015 http://www.ohchr.org/Documents/Issues/ClimateChange/COP21.pdf 7. 
protect the rights of affected people in this context, the Paris Agreement (PA) under the United Nations Framework Convention on Climate Change (UNFCCC), ${ }^{5}$ acknowledges for the first time in a multilateral environmental agreement that

\begin{abstract}
Parties should, when taking action to address climate change, respect, promote and consider their respective obligations on human rights, the right to health, the rights of indigenous peoples, local communities, migrants, children, persons with disabilities and people in vulnerable situations and the right to development, as well as gender equality, empowerment of women and intergenerational equity. ${ }^{6}$
\end{abstract}

Consequently, under the PA, States are called on to ensure that climaterelated actions safeguard the substantive and procedural rights enshrined in fundamental international human rights instruments. Although the reference to human rights in the PA is a "laudable step", it has to be noted that the treaty does not concretise implementation measures and such reference is not "self-operational", requiring further interpretation. ${ }^{7}$

In the context of climate change mitigation, the PA acknowledgment is especially relevant, as it has been observed that greenhouse gas (GHG) mitigation projects can also adversely affect the enjoyment of human rights. It has been the case, for example, of certain kinds of projects under the Clean Development Mechanism (CDM) of the Kyoto Protocol (KP) that have been linked to human rights violations. ${ }^{8}$

Under the PA, countries have established their own voluntary national mitigation objectives and have included them in their mandatory national climate strategies, known as Nationally Determined Contributions or NDCs. ${ }^{9}$ In order to support the achievement of these mitigation objectives, the PA includes, among others, voluntary cooperative approaches that countries

5 Paris Agreement (2015). After years of deadlocked international negotiations following the adoption of the Kyoto Protocol to the UNFCCC, the PA on climate change was adopted at the 21st Conference of the Parties to the UNFCCC (COP21) and formally entered into force on 4 November of 2016. This agreement, consisting of 29 articles and 16 preambular paragraphs, is a legally binding instrument (although with various non-binding elements) that seeks to enhance the implementation of the UNFCCC. Thus, although it is not perfect and not enough by itself to solve the climate crisis, the PA establishes a reinforced framework of action (on both mitigation and adaptation) that applies to all developed and developing countries and aims at strengthening the global response to the threat of climate change. On the PA see, for example, Bodansky 2016 AJIL 288-319; Savaresi 2016 JENRL 16-26; Clémençon 2016 JED 3-24.

6 Preamble, Paris Agreement (2015). Ajibade 2016 JSDLP 73.

See discussion in part 4.

Articles 3 and 4 of the Paris Agreement (2015). 
can use on a voluntary basis. One of these approaches is the new (informally called) Sustainable Development Mechanism or SDM, aimed at reducing GHG emissions, while fostering sustainable development.

As with the CDM, the SDM can enable the emergence of a large offset mechanism providing countries with the flexibility to attain emissions reductions outside of their jurisdiction. ${ }^{10}$ However, it can also lead to the implementation of mitigation projects that may raise human rights concerns, especially if they are ineffectively designed and prioritise economic aspects. The question explored in the present study is the following: how could the SDM be designed in order to ensure the respect and protection of human rights during its implementation and operation? The aforementioned human rights language of the PA provides a mandate and an entry point for considering human rights issues in the context of the SDM and its governing rules and procedures. ${ }^{11}$ By doing so, the SDM can help to satisfy the compelling need to operationalise and give effect to the human rights language of the PA in climate-related processes and activities in order not to jeopardise human rights or to repeat past mistakes and climate injustices. It is in this context that this paper is written.

Based on a desktop analysis, this paper aims to provide theoretical and factual arguments for considering the integration of human rights issues into the SDM of the PA. The paper argues that the lessons learned from previous international mitigation mechanisms established under the UNFCCC which have been linked to human rights concerns, as the case of the CDM, should be considered for the design and implementation of the modalities and procedures of the SDM in order to prevent potential conflicts and human rights harms.

Following the introduction, this paper first considers the incorporation of human rights language into the international climate change regime and its relevance in the context of climate change-related actions. The paper then moves to an analysis of the SDM, its objectives and main characteristics as defined in the PA. In order to shed light on human rights issues that can be taken into account when developing the SDM's rules, the next section focuses on the CDM that shares many similarities with the SDM. By using a human rights lens, this section draws attention to the shortcomings of the CDM and analyses the human rights concerns relating to its implementation. Finally, based on the experience and lessons learned from

Dahan et al 2016 Climate Brief 5.

Holm Olsen, Arens and Mersmann 2017 Climate Policy 8. 
the CDM, some recommendations are proposed to facilitate the incorporation of human rights issues within the rules, modalities and procedures of the SDM in order to make it consistent with existing human rights obligations, standards and principles.

\section{The integration of human rights language into the climate change regime and the Paris Agreement}

The linkages between human rights and climate change have gained increasing attention over the last decade and nowadays they are beyond dispute.

While numerous academic publications have stressed the human rightsclimate change nexus, ${ }^{12}$ at international level different organs of the United Nations (UN) system have also recognised this relationship in a diversity of resolutions and reports. For example, in 2008 the UN Human Rights Council (HRC) adopted its first resolution on human rights and climate change. ${ }^{13}$ The adoption of this resolution took place after two key events that had sparked an international dialogue about the human rights implications of climate change in previous years: a petition submitted by the Inuit Circumpolar Conference to the Inter-American Commission on Human Rights in December 2005 against the United States which established the critical linkages between climate change and human rights, ${ }^{14}$ and the adoption in 2007 of the Malé Declaration on the Human Dimension of Global Climate Change. ${ }^{15}$ Thus, for the first time in an official UN resolution, the Council recognised that climate change "poses an immediate and far-

12 See, for example, Humphreys Human Rights and Climate Change; Quirico and Boumghar Climate Change and Human Rights; Atapattu Human Rights Approaches. Resolution on Human Rights and Climate Change UNHRC Res 7/23, UN Doc A/HRC/7/78 (2008).

14 The petitioners alleged that by failing to reduce its emissions of GHG, the United States, the world's then largest contributor to global warming, had violated their fundamental human rights protected by international instruments. Although the petition did not proceed, it helped to illuminate the relationship between climate change and human rights and nourished the public debate. See Inuit Circumpolar Council $2005 \quad \mathrm{http} / / / w w w . i n u i t c i r c u m p o l a r . c o m / i n u i t-p e t i t i o n-i n t e r-a m e r i c a n-$ commission-on-human-rights-to-oppose-climate-change-caused-by-the-unitedstates-of-america.html.

15 The Declaration, adopted by the Small Island Developing States, was the first international agreement to explicitly recognise the implications of climate change for the enjoyment of human rights. Male' Declaration on the Human Dimension of Global Climate Change (2007). 
reaching threat to people and communities around the world and has implications for the full enjoyment of human rights". ${ }^{16}$

Since then, the HRC has issued five other resolutions noting and emphasising, among others, the implications of climate change for the effective enjoyment of several human rights, especially by the most vulnerable people; ${ }^{17}$ the potential of human rights obligations, standards and principles to inform and strengthen international and national policymaking in the area of climate change $;{ }^{18}$ the importance of addressing the impacts of climate change as they relate to State's human rights obligations and of enhancing international dialogue and cooperation in this regard ${ }^{19}$ the need to continue to address the adverse consequences of climate change and to facilitate interaction between human rights and climate change communities in order to build capacity to deliver effective climate change responses; ${ }^{20}$ and, more recently, the urgent necessity for States to integrate human rights in climate change - related efforts (mitigation and adaptation). ${ }^{21}$

Similarly, by noting that climate change interferes with a wide range of human rights, the UN High Commissioner for Human Rights $(\mathrm{OHCHR})$ and the Special Rapporteur on Human Rights and the Environment pointed out that under international human rights law States have duties to protect those rights from the effects of climate change and to ensure that their actions to tackle it do not infringe recognised human rights. ${ }^{22}$

Building on these aforementioned recognitions, the link between human rights and climate change has more recently "found a voice in the climate change discussion and resulting response actions". ${ }^{23}$ Although this

16 Resolution on Human Rights and Climate Change UNHRC Res 7/23, UN Doc A/HRC/7/78 (2008) para 1.

17 Resolution on Human Rights and Climate Change HRC Res 10/4, UN Doc A/HRC/10/4 (2009) Preamble. Resolution on Human Rights and Climate Change HRC Res 18/22, UN Doc A/HRC/18/22 (2011) Preamble.

19 Resolution on Human Rights and Climate Change HRC Res 26/27, UN Doc A/HRC/26/27 (2014) paras 3-5. Resolution on Human Rights and Climate Change HRC Res 29/15, UN Doc A/HRC/RES/29/15 (2015) Preamble and para 2.

21 Resolution on Human Rights and Climate Change HRC Res 32/33, UN Doc A/HRC/RES/32/33 (2016) Preamble and para 9.

22 OHCHR 2015 http://www.ohchr.org/Documents/lssues/ClimateChange/COP21.pdf 7; and Independent Expert on Human Rights and the Environment 2014 http://www.ohchr.org/EN/Issues/Environment/SREnvironment/Pages/ClimateChan ge.aspx. 
relationship received limited recognition in the context of the UNFCCC negotiations and its mechanisms, in 2010 States adopted the Cancun Agreements (CA) that, for the first time in an international climate agreement, include references to the link between human rights and climate change. ${ }^{24}$

Noting the second resolution 10/4 of the HRC on human rights and climate change, which recognises the implications of climate change for the effective enjoyment of human rights, ${ }^{25}$ the $\mathrm{CA}$ recognise that human rights obligations apply in the context of climate change. Thus, in order to protect the rights of those most vulnerable to the impacts of climate change as well as of those affected by mitigation and adaptation measures, the agreement states that "Parties should, in all climate change related actions, fully respect human rights". ${ }^{26}$ In addition, it also stresses the need to protect the participation rights of affected people in decision-making processes for effective climate action. ${ }^{27}$ The CA, therefore, do not only recognise the effects of climate change measures on human rights, but also point out the human rights obligations that apply to climate-related actions.

The incorporation of human-rights language in the CA was a significant first step towards establishing the need for human rights in the context of the climate framework. It became an acknowledgment that the international climate regime "needs to be designed in coherence with the human rights regime". ${ }^{28}$ Eventually, with such recognition the advocacy movement that largely called for the inclusion of human rights within the climate regime "achieved its first success".29

Over the following years, the progress achieved with the adoption of the CA in terms of human rights, together with the efforts of the HRC and the advocacy of civil society and other activist groups, inspired and motivated major demands for the integration of human rights considerations into the climate regime. Thus, the inclusion of human rights language within the "new protocol, another legal instrument or an agreed outcome with legal force" 30 under the UNFCCC, which should be adopted in 2015, was broadly

24 Decision 1/CP.16 - Cancun Agreements UN Doc FCCC/CP/2010/7/Add.1 (2011) (the Cancun Agreements).

25 Cancun Agreements, Preamble.

26 Cancun Agreements, para 8.

27 Cancun Agreements, para 7.

28 Schade and Obergassel 2014 Camb Rev Int Aff 718.

29 Mayer 2016 Climate Law 111.

30 Decision 1/CP.17 - Establishment of an Ad Hoc Working Group on the Durban Platform for Enhanced Action UN Doc FCCC /CP/2011/9/Add.1 (2012) paras 2-4. 
claimed. ${ }^{31}$ They also gave rise to additional demands for the recognition that all actions taken to address climate change should be fully in accordance with States' human rights obligations. ${ }^{32}$ As a result, although the international climate change negotiations that followed the COP in Cancun did not achieve further progress on this issue, in 2014 a reference to the obligation of parties to "respect human rights, the right to development and the right of indigenous people" was included in the so-called "elements for a draft negotiation text" annexed to the "Lima Call for Climate Action", an outcome of COP20, which laid the foundations for the new global climate deal. ${ }^{33}$

The wider call eventually culminated in the UNFCCC State Parties' decision to incorporate and acknowledge human rights considerations in the text of the PA, adopted in 2015 at COP21. By strengthening the statement of the CA and of the draft negotiation text of 2014 and acknowledging States' existing obligations, the preamble of the PA recognises that the Parties may be affected not only by climate change, but also by the impacts of the measures taken in response to it. Consequently, it explicitly acknowledges that

Parties should, when taking action to address climate change, respect, promote and consider their respective obligations on human rights. ${ }^{34}$

In this sense, the PA became the first climate change instrument and one of the first environmental agreements to explicitly recognise the relevance of human rights in the context of climate action.

The human rights language included in the agreement was a positive step forward and provided "a marginal victory for those advocating for building bridges between the climate change regime and human rights law". ${ }^{35}$ Although the PA fell short of adopting a rights-based approach for the implementation of its provisions, the human rights reference included in its text "[has] the potential to set in train the steps needed to protect people

\footnotetext{
31 See for example UN 2014 http://www.ohchr.org/Documents/HRBodies/ SP/SP_To_UNFCCC.pdf.

32 See, for example, OHCHR 2015 http://www.ohchr.org/EN/NewsEvents/ Pages/DisplayNews.aspx?NewsID=16836\&LangID=E.

33 Decision 1/CP.20 - Lima Call for Climate Action UN Doc FCCC/CP/2014/10/Add.1 (2015) annex, 6.

34 In relation to the debate on the human rights language of the PA as well as its legal force see, for example, Mayer 2016 Climate Law 109-117; Ajibade 2016 JSDLP 7374. 
living in the most vulnerable situations". ${ }^{36}$ Ultimately, it may be viewed "[...] as a powerful force for defending the human rights of the most vulnerable in our society from environmental change". ${ }^{37}$

Although the PA does not create an independent or self-standing human rights-related obligation, the human rights clause included in its preamble calls on Parties to take human rights into account and recognises States' obligation to fulfil their international human rights duties when carrying out climate-related actions under the new climate agreement, ${ }^{38}$ including the mitigation activities under the SDM. However, as with the CA, the PA does not include specifications about how countries should fulfil that obligation and, therefore, operationalise rights' protection. Thus, while being a "hopeful step in the right direction", the PA is just the beginning and "[w]hat is needed now is action - drastic, serious action" to implement its content. ${ }^{39}$

Giving effect to the human rights language of the new agreement and translate it into concrete actions and practices to ensure the protection for those affected by climate change and climate-related actions remains an important challenge that need to be addressed by the international community in the years to come..$^{40}$ While more work is needed to ensure that human rights principles guide the development and implementation of the climate policies, institutions, mechanisms and solutions established in the PA, this paper intends to provide the foundations for the operationalisation of the human rights language of the treaty in the context of the SDM in order to ensure its consistency and coherence with human rights law.

\section{The Sustainable Development Mechanism (SDM) of the Paris Agreement}

After years of deadlocked negotiations following the adoption of the KP, the PA has started a new era in global climate policy based on an internationally coordinated effort. Adopting a bottom up structure, the agreement leaves each country to determine how and how much they can contribute to meeting the long term climate goal - the most ambitious goal ever adopted in a climate accord - to hold global temperatures "well below $2^{\circ} \mathrm{C}$ above

\footnotetext{
36 Mary Robinson Foundation 2015 http://www.mrfcj.org/resources/statement-frommary-robinson-on-the-paris-agreement/.

Burns "Human Rights Dimensions of Bioenergy" 170.

Mayer 2016 Climate Law 113-114.

Atapattu "Justice for Small Island Nations" 322.

Ajibade 2016 JSDLP 80.
} 
pre-industrial levels and to pursue efforts to limit the temperature increase to $1.5^{\circ} \mathrm{C} " .41$ In this sense, countries have been requested to define their voluntary mitigation contribution or NDCs that basically provide information on what countries intend to do to tackle climate change. ${ }^{42}$ As of December 2017, 172 Parties had submitted their first NDCs to the Secretariat. ${ }^{43}$

The NDCs, which will become operational as of 2020, have become a key component of the PA. They are expected to deliver meaningful emission reductions and to slow down the emissions growth in the coming decades. ${ }^{44}$ However, despite these noble intentions, it has been identified that the outcome of the full implementation of the NDCs would still fall short of the $2^{\circ} \mathrm{C}$ long-term temperature objective. ${ }^{45}$ Parties' contributions will then need to be improved in years to come and to do so additional ways and mechanisms are required.

Due to the fact that cost-effective mechanisms may help to implement and fulfil the NDCs as well as to enhance ambition of future emission mitigation targets, the PA contains provisions for promoting voluntary cooperation amongst countries on climate action through mechanisms "that could provide frameworks for markets, climate finance or other forms of coordination". ${ }^{46}$

Concretely, article 6 of the PA, one of the last issues to be agreed upon during the last night of COP21 before the text was approved, ${ }^{47}$ recognises that

... some Parties choose to pursue voluntary cooperation in the implementation of their nationally determined contributions [NDCs] to allow for higher ambition

$41 \quad$ Article 2.1(a) of the Paris Agreement (2015).

42 Article 4.2 of the Paris Agreement (2015). See also Decision 1/CP.19 - Further Advancing the Durban Platform UN Doc FCCC/CP/2013/10/Add.1 (2014) para 2 (b); Decision 1/CP.20 - Lima Call for Climate Action UN Doc FCCC/CP/2014/10/Add.1 (2015) para 14; and Decision 1/CP.21 - Adoption of the Paris Agreement UN Doc FCCC/CP/2015/10/Add.1 (2016) para 13.

43 According to art 4.12 of the PA, the NDCs communicated by Parties shall be recorded in a public registry. See NDC Registry 2017 http://www4.unfccc.int/ndcregistry/Pages/Home.aspx.

44 UNFCCC $2015 \mathrm{http}: / /$ unfccc.int/resource/docs/2015/cop21/eng/07.pdf.

45 Streck, Keenlyside and Von Unger 2016 JEEPL 12.

46 Raeschke-Kessler 2016 CMR 8. The SDM is not the only possibility of the PA that could help to implement the agreement and enhance climate change mitigation ambition. Other tools and mechanisms on this regard include, inter alia, technology transfer, information sharing, low-carbon investment and finance.

47 About the negotiation process of article 6 of the PA see Marcu "Carbon Market Provisions". 
in their mitigation and adaptation actions and to promote sustainable development and environmental integrity. ${ }^{48}$

Article 6 includes three cooperation formats that are of great importance for the implementation of the PA as well as for increasing ambition and meeting the long-term emissions goal. ${ }^{49}$ Such cooperative approaches are: (i) transfers of mitigation outcomes (attained through cooperative approaches) between Parties, ${ }^{50}$ which could allow for bilaterally and multilaterally transferred emission reductions to account for Parties' NDCs; (ii) the sustainable development mechanism or SDM ${ }^{51}$ discussed below; and, (iii) a framework for non-market approaches to promote mitigation and adaptation ambition. ${ }^{52}$

The SDM, established in article 6.4 of the $P A,{ }^{53}$ is essentially a new baseline-and-credit mechanism available to all Parties, aimed at helping both developed and developing countries to achieve their mitigation objectives and increase ambition by generating emission reduction units, while fostering sustainable development. ${ }^{54}$ Thus, it has a dual mandate to contribute to the reduction of GHG emission levels and to promote sustainable development. ${ }^{55}$

$48 \quad$ Article 6.1 of the Paris Agreement (2015).

49 While many countries have claimed their intention to use the PA cooperative approaches to meet their emissions reduction goals and enhance ambition, the central role of these approaches depends on the rules that will guide their application. Streck, Keenlyside and Von Unger 2016 JEEPL 17.

$50 \quad$ Articles 6.2 and 6.3 of the Paris Agreement (2015).

51 Articles 6.4 to 6.7 of the Paris Agreement (2015).

52 Articles 6.8 and 6.9 of the Paris Agreement (2015).

53 This mechanism was defined on the basis of a proposal submitted by the Government of Brazil to the UNFCCC, regarding the elements of a new agreement under the Convention. The Brazilian proposal provided for the creation of a new market mechanism, "an enhanced CDM", as a complementary tool to achieve the NDCs. Such mechanism "[...] should be established under the agreement, incorporating the modalities, procedures and methodologies of the [CDM], to allow trading of CER among all parties". Government of Brazil 2014 http://www4.unfccc.int/submissions/Lists/OSPSubmissionUpload/73_99_13060210 4651393682-BRAZIL\%20ADP\%20Elements.pdf.

54 Others have proposed to call the mechanism Sustainable Mitigation Mechanism or SMM due to its dual aim. See Holm Olsen, Arens and Mersmann 2017 Climate Policy 2.

55 Article 6.4(a) of the Paris Agreement (2015). 
According to the PA, the SDM is under the authority and guidance of the Conference of the Parties serving as the meeting of the Parties to the PA $(\mathrm{CMA})^{56}$ and its supervision is in charge of a body designated by the CMA. ${ }^{57}$

The SDM activities (programmes and projects) can be hosted by all Parties and the mitigation outcomes or emissions reductions resulting from them can be used by the same host Party to demonstrate achievement of its NDC or be transferred and used by another Party for the same purpose. ${ }^{58}$ The reductions resulting, however, should only be used by one Party in order to avoid double counting of emissions reductions achieved. ${ }^{59}$

As pointed out by Raeschke-Kessler, the PA provisions related to the SDM contain "several concepts which are clearly inspired by the mechanisms of the KP", 60 especially by the CDM, to which further reference will be made below in part 4. For example, the SDM and the CDM both have a dual objective of supporting mitigation actions as well as fostering sustainable development. ${ }^{61}$ In addition, both mechanisms are expected to create real, measurable and long-term benefits related to their objectives. ${ }^{62}$ Likewise, the reductions achieved by mitigation activities or actions under both mechanisms (in the case of the SDM they are yet to be defined) must be additional ${ }^{63}$ and they should be verified and certified by designated operational entities, a kind of accredited independent auditors. ${ }^{64}$ Regarding the participants, the CDM and SDM provide for participation of private and public entities in the development of mitigation activities, and that participation needs to be authorised by their governments. ${ }^{65}$ Moreover, both mechanisms foresee provisions for the use of a "share of the proceeds" from mitigation activities to cover administrative expenses and to assist developing countries to meet the cost of climate change adaptation. ${ }^{66}$

56 The first session of the CMA took place in 2016 in Marrakech in conjunction with the COP22 and the Conference of the Parties, serving as the Meeting of the Parties to the KP (CMP12).

$57 \quad$ Article 6.4 of the Paris Agreement (2015).

58 Article 6.4(c) of the Paris Agreement (2015).

59 Article 6.5 of the Paris Agreement (2015).

60 Raeschke-Kessler 2016 CMR 10.

$61 \quad$ Article 12.2 of the Kyoto Protocol (1997); art 6.4(a) of the Paris Agreement (2015).

62 Article 12.5(b) of the Kyoto Protocol (1997); Decision 1/CP.21 - Adoption of the Paris Agreement UN Doc FCCC/CP/2015/10/Add.1 (2016) para 37(b). Article 12.5(c) of the Kyoto Protocol (1997); Decision 1/CP.21 - Adoption of the Paris Agreement UN Doc FCCC/CP/2015/10/Add.1 (2016) para 37(d). Article 12.5 of the Kyoto Protocol (1997); Decision 1/CP.21 - Adoption of the Paris Agreement UN Doc FCCC/CP/2015/10/Add.1 (2016) para 37(e). Article 12.9 of the Kyoto Protocol (1997); art 6.4(b) of the Paris Agreement (2015). Article 12.8 of the Kyoto Protocol (1997); art 6.6 of the Paris Agreement (2015). 
However, there are also important differences between the SDM and the $\mathrm{CDM}$. For instance, while the CDM allows the development of mitigation activities only in developing countries, SDM activities can be hosted by both developed and developing countries without any restriction. Unlike the CDM, the SDM should deliver an overall mitigation in global emissions going beyond pure offsetting. ${ }^{67}$ Other differences may arise in the future as the rules, modalities and procedures for the implementation of the SDM will be developed and adopted by the CMA in $2018 .{ }^{68}$

An important element, especially relevant for the aim of this paper, is that it has been stated that the SDM, its modalities and procedures for its operation should be built on the basis of, among other things, the experience gained with and lessons learned from existing mechanisms and approaches. ${ }^{69}$ That is to say that the Flexible Mechanisms of the KP, such as the CDM, serves as a basis for the new mechanism. It has been argued that because of their similarities it would be highly desirable to use the CDM system as the core of the SDM. ${ }^{70}$

In this sense, the CDM's experience could be used to clarify technical details and standards for the implementation of the $\mathrm{SDM}^{71}$ for example, in relation to the assessment of sustainable development outcomes. ${ }^{72}$ Besides this, it is also necessary and pertinent to look at the lessons learned from it with regard to human rights issues as they can provide worthwhile inputs for operationalising the human rights reference of the PA, while ensuring that the SDM moves forward and protects human rights. The next part briefly draws attention to this issue.

\section{Human rights considerations in existing mitigation mechanisms under the UNFCCC: the case of the CDM}

The CDM, defined by article 12 of the KP, is an offset mechanism that allows developed countries to invest in cost-effective mitigation projects in developing countries. These projects are intended to generate carbon

\footnotetext{
67 Article 6.4(d) of the Paris Agreement (2015).

68 Decision 1/CP.21 - Adoption of the Paris Agreement UN Doc FCCC/CP/2015/10/Add.1 (2016) para 38.

69 Decision 1/CP.21 - Adoption of the Paris Agreement UN Doc FCCC/CP/2015/10/Add.1 (2016) para 37(f). Michaelowa and Hoch 2016 CMR 31.

71 There are many issues that need to be addressed related the new mechanism, for example: how to assess sustainable development outcomes, how to deliver net mitigation, or how to avoid double counting, among others. 
credits, so-called Certified Emission Reductions (CERs), each of which equals to one metric ton of $\mathrm{CO}_{2}$, which can be used by developed countries to fulfil part of their GHG emissions reduction commitments or be traded on international carbon markets. As a win-win solution, in addition to provide developed countries with some flexibility to meet their mitigation targets, the CDM should also assist developing countries in achieving sustainable development. ${ }^{73}$

Since the registration of the first CDM project in 2004, more than 7700 projects in over 100 countries have been registered by the Executive Board (EB), the body that supervises the functioning of the mechanism and that issues the CERs. ${ }^{74}$ Although the distribution of projects under the CDM has been characterised for being inequitable - due to the dominance of only few countries, especially China and India - generally speaking it can be said that the CDM played an important role in encouraging developing countries to participate to the global GHG emissions reduction effort. ${ }^{75}$ In addition, it has been argued that one of the successes of the mechanism has been to attract finance into mitigation projects in developing countries; in fact by 2015 it had mobilised more than US $\$ 215.4$ billion in foreign investments, providing opportunities for socio-economic growth and poverty alleviation in many host countries. ${ }^{76}$ As a result, over the past decade the CDM has helped to mitigate more than one billion tonnes of GHG and, therefore, as of July 2017, more than 1.8 billion CERs were issued under the mechanism. For this reason, the CDM became the main generator of carbon-offset credits worldwide, contributing substantially to the development of a global carbon market.

However, being a first-of-a-kind international climate change mitigation instrument, the CDM followed a learning-by-doing pattern and its implementation has known challenges. Since its inception and through a long and complex growing process many concerns and criticisms about environmental integrity ${ }^{77}$ and additionality, ${ }^{78}$ financing, ${ }^{79}$ geographical distribution, ${ }^{80}$ and contribution to sustainable development of CDM

\footnotetext{
$73 \quad$ Article 12.2 of the Kyoto Protocol (1997).

74 See UNFCCC's CDM (UNFCC 2017 https://cdm.unfccc.int/).

75 See statistics on distribution per host country of CDM projects (UNFCC 2017 https://cdm.unfccc.int/Statistics/Public/CDMinsights/index.html).

76 Olawuyi Human Rights-Based Approach to Carbon Finance 8.

77 See, for example, Voigt "Responsability for the Environmental Integrity of the CDM".

78 See, for example, Schneider 2009 Climate Policy 242-25; Alexeew et al 2010 Int Environ Agreem 233.

79 See, for example Lütken and Michaelowa Corporate Strategies.

80 See for example, Eni-ibukun "Climate Justice".
} 
projects, ${ }^{81}$ to name just a few, have been raised. Furthermore, concerns over human rights abuses during the implementation of projects have accompanied the mechanism. In order to address these issues, the CDM underwent different reforms throughout its almost 15-years history. During these years many lessons have been learned. Some of these lessons, specially related to human rights issues, are discussed below.

\title{
4.1 The absence of human rights considerations in the CDM rules
}

The CDM basically had a climate-centric focus. ${ }^{82}$ As Morten argues, it "was established without any concern for human rights impacts of its projects". 83 Consequently, its rules, modalities and procedures do not include references to human rights. ${ }^{84}$ The lack of attention to human rights within the mechanism was not an isolated issue. Olawuyi claims that

\begin{abstract}
Before now, most of the focus had been on the direct impacts of climate change on human rights, thereby obscuring discussions on how policy measures and projects aimed at combating climate change are currently producing human rights violations. Scholarly and policy discussions at the intersection of human rights and climate change failed to consider in great detail, the legal and institutional frameworks required to incorporate human rights issues into climate projects. ${ }^{85}$
\end{abstract}

In the course of the years, difficulties to establish a holistic understanding of how human rights should be functionally addressed in climate change mitigation projects became widespread in the context of the CDM. Therefore, "[a]ssuring respect for human rights within CDM projects has shown to be inherently difficult". 86

Although the CDM was conceived to meet two simultaneous goals (climate change mitigation and sustainable development), its rules were focused on achieving GHG emission reductions as it was the sole purpose of projects. Thus, the CDM system values, validates, monitors, certifies and provides a monetary value to the emission reductions achieved by a project when they are additional to any other that would occur in the absence of it. ${ }^{87}$ In this

81 See for example, Olsen 2007 Climatic Change 59; Sutter and Parreño 2007 Climatic Change 75; Boyd et al 2009 Environ Sci Policy 820; Sterk et al Further Development of the Project Based Mechanisms; and Wilson 2011 Ecology L Q 967. Holm Olsen, Arens and Mersmann 2017 Climate Policy 9.

$83 \quad$ Morten Haugen 2013 Nord Envtl L J 51.

84 The rules of the CDM were adopted in 2001 as part of the Marrakesh Accords. See Decision 3/CMP. 1 - Modalities and Procedures for a Clean Development Mechanism as Defined in Article 12 of the Kyoto Protocol UN Doc FCCC/KP/CMP/2005/8/Add.1 (2006).

85 Olawuyi 2016 JENRL 30.

$86 \quad$ Filzmoser et al 2015 http://orbit.dtu.dk/files/115264634/FILZMOSER.pdf 18.

87 Article 12.5 of the Kyoto Protocol (1997). 
context, while the respect and enforcement of human rights is a precondition for sustainable development, ${ }^{88}$ neither the contribution of projects to sustainable development nor their compliance with human rights are assessed and guaranteed. The international control bodies, concretely the CDM EB and the Designated Operational Entities (DOEs) that verify, validate and certify the emission reductions achieved by a specific CDM project, do not have a mandate to ascertain such contribution or compliance - neither during the project design, nor during its operative stage. As a consequence, failing to meet these is neither an obstacle to the registration and certification of projects, nor for the issue of CERs.

The absence of human rights considerations combined with the philosophy behind the CDM to achieve cheaper emissions reductions in developing countries compared to those that could be achieved in developed countries, allowed the efforts to mainly focus on maximising the generation of CERs without paying equal attention to social and human rights issues. ${ }^{89} \mathrm{In}$ fact, while many CDM projects would have contributed especially to the economic and environmental dimensions of sustainable development, as they led to the mitigation of GHG emissions, the social contribution of projects remained underrepresented in the mechanism. ${ }^{90}$

Furthermore, strong accusations of supporting projects with serious human rights violations have gone hand in hand with the mechanism for many years. In addition to have caused significant negative impacts on the environment, ${ }^{91}$ the implementation of several CDM projects has been linked to human rights violations and abuses against local communities and indigenous people, affecting their livelihood and exacerbating already existing social and economic problems. ${ }^{92}$ These projects usually affect the poorest and most vulnerable people who have little if any power in decisionmaking processes. In some countries, CDM projects also caused directly or

88 Based on this, for example, during the global debate of the 2030 Agenda for Sustainable Development and its Sustainable Development Goals the integration of human rights issues was repeatedly claimed by several actors. See UN Development Group 2013 http://www.ohchr.org/Documents/Issues/MDGs/UNDGAMillionVoices.pdf. See, for example, Olsen 2007 Climatic Change 59; Schatz 2008 GIELR 704. UNFCCC 2011 https://cdm.unfccc.int/about/dev ben/index.html 12.

91 It is the case, for example, of hydroelectric CDM projects. See Haya and Parekh 2011 https://carbonmarketwatch.org/wp-content/uploads/2011/11/Haya-Parekh2011-Hydropower-in-the-CDM.pdf.

92 See, for example, Voigt "Deadlock of the Clean Development Mechanism"; Zagema 2011 https://www.oxfam.org/en/research/land-and-power; Olawuyi "Fostering Accountability in Large-Scale" 129; Schade and Obergassel 2014 Camb Rev Int Aff 717; Filzmoser et al 2015 http://orbit.dtu.dk/files/ 115264634/FILZMOSER.pdf 7-13. 
indirectly displacements, social conflicts and repressions that affected the full enjoyment of human rights, including the right to life, health, safety and physical and psychological integrity. ${ }^{93}$ Agencies responsible for promoting and protecting human rights confirmed the infringement of human rights occurring as a result of CDM projects. ${ }^{94}$ Examples of CDM projects that have led to concerns about human rights issues include Santa Rita hydro project in Guatemala, ${ }^{95}$ Barro Blanco hydro project in Panama, ${ }^{96}$ KwaleOkpai gas recovery project in Nigeria, ${ }^{97}$ Aguan biogas project in Honduras, ${ }^{98}$ Sasan coal power project in India, ${ }^{99}$ and the Bisasar road landfill gas project in South Africa, ${ }^{100}$ among others.

While the rules of the mechanism require project-specific environmental impact assessments (EIA), ${ }^{101}$ these evaluations are developed without considering or addressing the human rights impacts of projects. The comments and claims on these issues, therefore, neither appear in the Project Design Document (PDD), nor in the validation or verification reports drafted by the DOEs. On several occasions affected people and nongovernmental organisations made the CDM EB aware of the severe human rights violations taking place during the implementation of projects, but it has so far not intervened. In fact, it argued the lack of a mandate to address human rights concerns or investigate abuses of approved projects. Although the CDM EB acknowledged being confronted with the issue of human rights, ${ }^{102}$ it has, however, approved the registration of projects despite the evidence of serious human rights abuses. ${ }^{103}$

\subsection{Deficient stakeholder's consultations}

\footnotetext{
93 Olawuyi Human Rights-Based Approach to Carbon Finance 9. http://www.cidh.org/countryrep/Honduras10eng/Honduras10.Situation.htm.

2010 Carbon Market Watch 2014 https://carbonmarketwatch.org/2014/04/14/santa-ritalarge-hydro-power-project-guatemala-2/.

Environmental Justice Atlas 2014 https://ejatlas.org/conflict/kwale-okpai-cdmproject-nigeria.

FIDH et al 2011 https://www.fidh.org/lMG/pdf/honduras573ang.pdf.

BankTrack 2016 https://www.banktrack.org/project/sasan_ultra_mega_coal_power _project_umpp_/pdf.

Bond Durban's Climate Gamble.

Decision 3/CMP. 1 - Modalities and Procedures for a Clean Development Mechanism as Defined in Article 12 of the Kyoto Protocol UN Doc FCCC/KP/CMP/2005/8/Add.1 (2006), para 37(c).

CDM EB 2011 http://unfccc.int/resource/docs/publications/cdm_annual_report 2011.pdf 13.

103 See, for example, Felipe Perez et al 2016 LEAD 3.
} 
Stakeholder consultation is mandatory for CDM projects. The CDM rules require the development of public consultation processes with all relevant stakeholders at local and global levels. ${ }^{104}$ However, the rules of the mechanism were not designed to effectively protect affected people's participatory rights and their access to information. For example, they do not provide further specifications on how local stakeholder consultations should be conducted, nor who must be informed and consulted. Thus, it has been argued that the mechanism rules regarding stakeholder consultations are "quite general and [...], poorly defined, regulated and documented". 105

Due to the lack of internationally agreed procedures for stakeholder consultations, the definition of related rules have been left to the discretion of the national government of the host country and project developers. However, many times they have not been able to define clear criteria for consultation processes and when they did it, the lack of a clear relationship between the CDM rules and national stakeholder consultations rules were evident. ${ }^{106}$ As a consequence, limited public participation opportunities and malpractices related to stakeholder consultations have arisen over the years. ${ }^{107}$ Hence, some stakeholder consultations have been characterised for being non-transparent, rudimentary, insufficient, inappropriate, and poorly documented. ${ }^{108}$ Due to this fact, the participation of stakeholders has not always been effective and opportune, neither during the design of projects nor during their implementation. As affected people often do not have the opportunity to receive, analyse and understand project information, they are consequently excluded from decision-making processes. ${ }^{109}$

On the basis of the above, it has been noted that

... the CDM, as it currently stands, excludes stakeholders and NGOs from effective participation in project design and implementation by failing to make vital information available, by making it available too late, and by using

104 Decision 3/CMP.1 - Modalities and Procedures for a Clean Development Mechanism as Defined in Article 12 of the Kyoto Protocol UN Doc FCCC/KP/CMP/2005/8/Add.1 (2006), paras 37(b) and 40(c).

105 Dong and Holm Olsen 2015 Climate Policy 173.

106 Dong and Holm Olsen 2015 Climate Policy 170.

107 This happened, for example, in the case of the Sasan coal power project in India and Santa Rita hydro project in Guatemala. BankTrack 2016 https://www.banktrack.org/project/sasan_ultra_mega_coal_power_project_umpp_/ pdf; Carbon Market Watch 2014 https://carbonmarketwatch.org/2014/04/14/santarita-large-hydro-power-project-guatemala-2/.

108 See Olsen 2007 Climatic Change 59; Dong and Holm Olsen 2015 Climate Policy 171; Wilson 2011 Ecology L Q 997-1003; Olawuyi "Fostering Accountability in LargeScale" 141.

109 See for example, Carbon Market Watch 2014 https://carbonmarketwatch.org/ 2014/04/14/santa-rita-large-hydro-power-project-guatemala-2/. 
culturally inappropriate avenues of communication to notify and inform stakeholders of projects. ${ }^{110}$

In addition, deficient procedures for local stakeholder consultations in the CDM have been linked to large-scale forced displacement and marginalisation of local actors and indigenous people ignoring their rights and without providing them with opportunities to properly discuss compensation measures for damages resulting from projects. ${ }^{111}$ Thus, despite evidence of negative impacts on affected people' participation rights, as well as their strong opposition, the CDM EB registered controversial CDM projects. ${ }^{112}$

\subsection{Absence of a grievance mechanism}

Another pitfall of the CDM that restricted its ability to comply with human rights standards was the absence of a grievance mechanism allowing affected people to bring complaints against a registered CDM project. Despite many years of debate around this issue, the current rules of the mechanism do not yet provide any mechanism for addressing problems that could arise on the operational level. The lack of such grievance mechanism has prevented people adversely affected or likely to be adversely affected by a contested and registered CDM project from requiring its review, block or withdrawal of approval until the facts have been clarified. In rare occasions investors backed out of the project when human rights violations were reported. ${ }^{113}$ Some affected people also submitted complaints to independent accountability mechanisms against investors for funding totally or partially projects threatening their rights. ${ }^{114}$ Yet, there were a few occasions "where financing has been withdrawn as a result of problems exposed, in part, through the work of these mechanisms". ${ }^{115}$ As a result, projects are able to continue without addressing human rights risks or infringements.

\footnotetext{
110 Wilson 2011 Ecology $L Q 1000$.

111 See, for example, the case of CDM forestry projects in Uganda, in Bond et al 2012 http://www.ejolt.org/2012/12/the-cdm-cannot-deliver-the-money-to-africa-why-thecarbon-trading-gamble-won\%E2\%80\%99t-save-the-planet-from-climate-changeand-how-african-civil-society-is-resisting 69-70.

112 For example, Panama's Barro Blanco CDM Project and Hondurans' Aguan Biogas Project. See Felipe Perez et al 2016 LEAD 3; Romanin Jacur "Promoting Investments in Sustainable Development" 175.

113 For example the case of the World Bank' withdrawal from the Bisasar Road LandfillGas CDM project in Durban, South Africa. See Bond Durban's Climate Gamble.

114 This has been the case, for example, of communities affected by Panama's Barro Blanco hydro project. See Felipe Perez et al 2016 LEAD 15-16.

115 Turner A Substantive Environmental Right 171.
} 
In view of these concerns, in 2013 the CDM EB approved a procedure to withdraw approval or authorisation of a CDM project that does not meet national standards or sustainable development objectives. ${ }^{116}$ This procedure, however, is not opened to stakeholders or affected people and leaves the final decision to the government of the host country. Yet, even when irregularities or human rights violations are obvious, governments may not take such decision, especially those who are willing to attract more projects by establishing lower requirements or standards, or engaging in acts of corruption. ${ }^{117}$

In addition, there are currently no mechanisms to submit grievances about the impacts of a CDM project or to appeal decisions made by the CDM EB. The establishment of an appeal procedure and a grievance mechanism has been discussed for years under the UNFCCC, but no agreement was reached in this regard. Filzmoser et al note that the lack of an effective grievance mechanism possesses negative human rights implications for the mechanism as a whole. While such absence denies affected people a platform through which their voices can be heard, it is contrary to the principle of accountability and "presupposes rather wrongly that the CDM can never provoke agitations, which is not the case". ${ }^{118}$

Due to criticisms and human rights concerns on the CDM system, ${ }^{119}$ in 2011 the CDM EB convened an independent high-level panel to conduct a dialogue on the past experiences and future challenges of the mechanism. ${ }^{120}$ The final report of the so-called CDM Policy Dialogue identified, among others, the human rights impacts of CDM projects on local communities and stressed the need for fundamental reform of the CDM's operating procedures. ${ }^{121}$ It, inter alia, called for action to ensure the contribution of CDM projects to achieve sustainable development; to improve stakeholder participation; and to establish an independent mechanism for appeals and grievances. However, no guidelines for achieving this reform were provided by the Panel. ${ }^{122}$ According to Michaelowa, although such recommendations would be helpful, some nondemocratic countries had expressed their opposition to some of them,

\footnotetext{
116 CDM EB 2013 http://cdm.unfccc.int/Reference/catalogue/document?doc id $=000003494$.

Brown 2010 Ecology L Q 246-251.

Filzmoser et al 2015 http://orbit.dtu.dk/files/115264634/FILZMOSER.pdf 9-10.

Especially from NGOs such as International Rivers, CIEL, and Carbon Market Watch, among others.

120 See CDM Policy Dialogue 2012 http://www.cdmpolicydialogue.org/.

121 CDM Policy Dialogue 2012 http://www.cdmpolicydialogue.org/report/rpt110912.pdf,

122 Olawuyi Human Rights-Based Approach to Carbon Finance 19.
} 
especially to improvements of local stakeholder consultation. ${ }^{123}$ In addition, the debate around an appeal mechanism had already started at the COP; however, such debate did not make improvements "due to insurmountable conflict between governments". ${ }^{124}$ Eventually, none of the Panel's recommendations were implemented.

Similarly, in an effort to address the criticisms on the CDM, especially related to its contribution to sustainable development and stakeholder consultations, in 2012 the CDM EB approved a voluntary sustainable development tool (SD tool) giving an important step forward. ${ }^{125}$ However, it still has important limitations. First, while it has not been designed following a human rights framework, the SD tool was adopted to measure only the positive impacts of a CDM project or its sustainable development cobenefits. Consequently, there are no provisions to include information on its negative impacts. ${ }^{126}$ Besides, the claimed benefits are neither monitored nor verified. Second, the tool was thought to be used exclusively by project participants; other stakeholders are not allowed to use it. Third, despite criticisms over the years, the tool does not contain requirements for improved local stakeholder consultations. Thus, it has been argued that

... the SD tool in its current form faces a number of weaknesses that limit its usefulness for meaningful assessments of the impacts on Sustainable Development a CDM project may have. ${ }^{127}$

With regards to human rights concerns, in 2015 the CDM EB decided that the submitted stakeholder comments related to human rights issues will be forwarded to the relevant human rights bodies within the UN system and within the host government. ${ }^{128}$ Nevertheless, it has not created a specific body under its own control for the investigation of these issues. The EB approved new rules related to consultation of stakeholders; however, such rules still fall short of addressing properly the longstanding concerns related

\footnotetext{
123 Michaelowa 2013 Climate Policy 409.

124 Michaelowa 2013 Climate Policy 409.

125 CDM EB 2012 http://www.kyomecha.org/document/CDM/EB70/eb70 annotation/eb70_Annex20_Draft_Tool_Sustainable_dev_co-

benefits_description_for_CDM_project_activities_and_PoAs.pdf. As of June 2017, 50 reports using the SD tool have been registered on the website of the tool (UNFCC $2017 \mathrm{http}: / /$ cdmcobenefits.unfccc.int).

126 The CDM EB argued that the mandate from the CMP when designing the tool was to highlight the co-benefits of CDM projects, but not the negative impacts. Holm Olsen, Arens and Mersmann 2017 Climate Policy 3.

127 Arens et al 2015 http://orbit.dtu.dk/files/115264238/Reforming_the CDM_SD_Tool.pdf 8.

128 CDM EB $2015 \quad$ https://cdm.unfccc.int/filestorage/A/6/5/A65DM 07YFCU3JKIQRTZXOV1BGENPSL/eb87_meeting_report.pdf?t=Q1h8b3hnbXI4fD BGYAy3HP7Xmlr_oyQ377mu para 52.
} 
to, for example, inappropriate language of the project information provided. ${ }^{129}$ Thus, while constituting an important step forward, the improvements on the mechanism are not enough to prevent human rights infringements in the implementation of projects.

In the light of the foregoing, the CDM shows that, while helping to fight climate change, certain mitigation projects could also have negative impacts on the enjoyment of human rights. It also exemplifies how very sensitive issues, like human rights, need to be addressed from the earliest stages, as they may be overshadowed by others of more political interest. Thus, it reveals that to be sustainable over time, to have the social legitimacy and to be able to provide investors with confidence, security and certainty, the rights of local communities and indigenous people need to be recognised and respected when mitigation measures are implemented. ${ }^{130}$ The CDM reality provides, therefore, a good opportunity to use its experience and lessons learned in the design of the SDM rules in order to enhance the protection of human rights. Precisely, some recommendations in this regard are proposed in the following part.

\section{Incorporating human rights into the SDM: some recommendations}

In order to avoid repeating the same mistakes which were made with the CDM, restore confidence in mitigation mechanisms and carbon markets, and prevent future resistance to viable projects, the SDM should integrate better human rights safeguards to ensure that human rights are respected in the implementation of mitigation activities. The integration of social and environmental safeguards that help to protect the rights of project-affected people and communities has already occurred, for example, in the context of climate financing mechanisms, including the Global Environmental Facility and the Reducing Emissions from Deforestation and Forest Degradation, and enhancing forest carbon stocks in developing countries (REDD+) Program. ${ }^{131}$ While the integration of such safeguards within the SDM could still face some political, technical and practical challenges, for examples in terms of political will, time, capacity building and types of expertise required, the significant steps done towards advancing rights

129 See, for example, CDM EB 2015 https://cdm.unfccc.int/filestorage/5/2/C/ 52CZAHLKPTQ7BE4GYOWV8INSJR9UF0/eb87_repan12.pdf?t=RFR8b3hnbHJ0f DCwOJ_9zH_vbXyWVv-mUoJL.

130 Dehm $2016 \bar{J} H R E 189$.

131 See, for example, Johl and Lador 2012 http://www.ciel.org/reports/a-human-rightsbased-approach-to-climate-finance-johl-lador-february-2012-3/. 
protections in the context of climate finance are of great importance as they demonstrate the feasibility of such improvements and their potential to guide the design of the SDM. The following are recommendations that may be considered in the development of the modalities and procedures of the SDM.

\subsection{Including a human rights language}

The recognition of the PA that human rights should be respected in all climate related actions provides the mandate and the basis for integrating human rights language into the rules, modalities and procedures of the SDM. Building on the language of the CA and PA, the rules of the new mechanism should include a reference highlighting that countries, when undertaking activities under the SDM, should respect, protect and fulfil human rights. Although such language reflects countries' existing obligations to protect human rights, past experience with international climate cooperation reveals the importance of including explicit references to human rights obligations. Doing this ensures that the mitigation activities under the SDM do not cause further harm and are implemented in accordance with human rights norms.

\subsection{Human rights impact assessment}

In order to promote the adequate ex-ante, intermediate and ex-post assessment of human rights impacts from SDM activities, the modalities and procedures of the mechanism should require all activities to undertake timely, independent and transparent human rights impact assessments (HRIAs).

In addition to contributing to make operational the PA's human rights considerations, the incorporation of a HRIA requirement within the SDM can help to ensure that the mitigation activities respect human rights, while avoiding contradiction with minimum human rights thresholds. HRIAs can help focus on concerns that often do not receive sufficient attention in standard impact assessments, and introduce distinct normative, moral and legal elements into the assessment process. ${ }^{132}$

The development of HRIAs has important advantages that could help the whole mechanism. HRIAs could help to assess systematically and openly the potential or actual impacts of a SDM activity on the human rights of affected or potentially affected people, underscoring the interrelationship

132 Nordic Trust Fund Human Rights Impact Assessments 7-10. 
between rights concerns and obligations. They contribute to identify all potentially affected and under-represented people and to recognise and address the uneven distribution of positive and negative effects on a SDM activity. By using a human rights framework for assessing impacts of SDM activities, HRIAs can also identify opportunities to prevent abuses before they occur and propose feasible alternatives or changes to mitigate or redress harms. Moreover, they could also contribute to enrich the decisionmaking processes within the mechanism by ensuring participation of stakeholders. And, more importantly, undertaking HRIAs in the context of the SDM could help to avoid perpetuating human rights abuses and injustices. ${ }^{133}$

\subsection{Public participation and access to information}

While participation, as a basic human right in itself, has been characterised as a "precondition or catalyst for the realisation and enjoyment of other human rights", 134 access to information is a pre-requisite for effective participation in decision-making processes.

Along with other fundamental rights, the rights of participation and access to information are critical to efforts to address climate change. ${ }^{135}$ The UNFCCC recognises the importance of information and stakeholder participation in decision-making related to climate change and provides that countries should promote and facilitate information exchange and public participation in addressing climate change and its effects and developing adequate responses. ${ }^{136}$ Additionally, while the CA recognised the need to engage a broad range of stakeholders and to improve climate-related information for effective climate change action, ${ }^{137}$ the PA highlights the importance of public participation, public access to information and cooperation at all levels, being crucial for the global climate action. ${ }^{138}$

\footnotetext{
133 Tarek et al 2007 Cornell Int'l L J 149-152.

134 Report of the Special Rapporteur on Extreme Poverty and Human Rights UN Doc A/HRC/23/36 (2013) Summary 1.

135 Report of the Office of the United Nations High Commissioner for Human Rights on the Relationship between Climate Change and Human Rights UN Doc A/HRC/10/61 (2009) paras 78-79.

136 Articles $4.1(\mathrm{~h})$ and (i); and 6.a (ii) and (iii) of the United Nations Framework Convention on Climate Change (1992).

137 Decision 1/CP.16 - Cancun Agreements UN Doc FCCC/CP/2010/7/Add.1 (2011), for example paras 7, 12, 14 (i) and 72.

138 The PA emphasises on the importance of public participation and access to information in its preamble, as well as in art 4 related to mitigation, art 7 related to adaptation, art 6 on the cooperative approaches, and art 12 on education, training and public awareness.
} 
On this basis, access to information and public participation are critical in the context of the SDM. They can help minimising potential impacts and enhancing acceptance of SDM activities, precluding tensions that may lead to deterioration of local livelihoods, ensuring transparency and, ultimately, preventing human rights violations. While information should be available in a way that is complete, clear, understandable and culturally appropriate, participation and consultations processes should be promoted during the entire project cycle, including planning, design and implementation phases, in order to ensure effective participation and engagement of a wide range of stakeholders, while preventing and reducing harm.

In addition, as previous experiences have shown, general and ambiguous requirements for public consultation (at global and local levels) are not enough to ensure participation of affected people and communities. Thus, the SDM rules describing consultation processes should include clear and well-defined requirements for effective and inclusive stakeholder involvement, as well as guidance on how the consultation should be undertaken (in terms of location, frequency and timeline of public meetings) and who should be consulted with a view to prevent exclusion of key stakeholders and affected people. Due to the importance of these processes, the decision about how and who must be consulted should not be left to the discretion of national governments and projects developers. Then it is necessary to define general guidelines that should be applied in every country and in every project.

Furthermore, for SDM activities that may have potential adverse impacts on indigenous people it should be required to consult those people and communities and to seek free, prior and informed consent. ${ }^{139}$

\subsection{Grievance mechanism}

To ensure that the activities under the mechanism are designed and implemented in a manner that protects and respects human rights, the rules of the SDM should establish an independent grievance mechanism to which individuals or groups affected or concerned about human rights impacts resulting from the implementation of a mitigation activity can submit their complaints. Such mechanism should ensure that these claims are considered, addressed and solved in an independent, timely, reliable and respectful manner. By establishing an adequate and effective channel for the articulation and ventilation of grievances, SDM participants would

139 According to art 19 of the UN Declaration on the Rights of Indigenous Peoples Res 61/295, Annex, UN Doc A/RES/61/295 (2007). 
arguably show their willingness to be perceived as bearers of obligations for the respect of human rights that may benefit the integrity and credibility of the mechanism.

If well designed and implemented, a grievance mechanism in the SDM system could help to fulfil the PA human rights mandate. Such mechanism could also assist in the realisation of participation rights and access to remedies of affected people and communities. In addition, it would help to address affected or potentially affected people and communities' concerns and grievances before tensions appear and conflicts escalate. In fact, it would allow a "transparent resolution of conflicts", while avoiding situations of mistrust that may affect the entire mechanism. ${ }^{140}$ An effective grievance mechanism can also provide a channel through which affected people can gain recognition for legitimate concerns, ensuring the legitimacy of the SDM. On the contrary, the absence of such mechanism, as happened in the case of the CDM, may have a serious impact on the ability of affected individuals and groups to enjoy their human rights.

\section{Conclusion}

The PA took an important step toward addressing human rights in the climate regime. Yet, the human rights language included in the agreement needs to be operationalised in both, the rules related to the implementation, and the rules that govern the treaty's mechanisms, inter alia, the SDM.

To give effect to the human rights component of the PA, the modalities and procedures of the SDM should integrate a strong human rights component with a view to respecting and protecting human rights of affected people when projects are implemented, while avoiding negative outcomes that perpetuate climate injustices.

The experience gained from previous mechanisms under the UNFCCC, such as the CDM, can provide a helpful basis for developing the SDM rules, modalities and procedures. The mechanism could use, for example, the CDM related institutions or built on its principles. However, the SDM should also consider the several lessons learned from the CDM implementation, including those linked to human rights concerns and criticism that affected the integrity of that mechanism. The CDM's experience demonstrates how a viable mitigation project could result in human rights infringements if not designed to protect and respect those rights. Thus, in addition to including

140 Holm Olsen, Arens and Mersmann 2017 Climate Policy 9. 
human rights references, the rules that govern the implementation of the SDM should promote the assessment of human rights impacts or potential impacts of activities under the mechanism; strengthen informed and effective stakeholder involvement and participation in all stages of the SDM activities; and, facilitate access to an effective grievance mechanism that provides affected or potentially affected individuals or people with an accessible, transparent and fair process for addressing their complaints about the impacts of a SDM mitigation measure or activity. If the SDM is to succeed, these and other human rights safeguards should not be overlooked.

By incorporating human rights concerns in the context of the SDM rules, modalities and procedure, States have the opportunity to demonstrate that they are able to take past experiences into account not just to avoid making the same mistakes, but also to reveal that they are seriously committed to address climate change while protecting human rights.

\section{Bibliography}

\section{Literature}

Abate Climate Justice

Abate RS (ed) Climate Justice: Case Studies in Global and Regional Governance Challenges (Environmental Law Institute Washington DC 2016)

Ajibade 2016 JSDLP

Ajibade I "Distributive Justice and Human Rights in Climate Policy: The Long Road to Paris" 2016 JSDLP 65-80

Alexeew et al 2010 Int Environ Agreem

Alexeew $\mathrm{J}$ et al "An Analysis of the Relationship between the Additionality of CDM Projects and their Contribution to Sustainable Development" 2010 Environ. Agreem Polit Law Econ 233-248

Atapattu Human Rights Approaches

Atapattu SA Human Rights Approaches to Climate Change: Challenges and Opportunities (Routledge New York 2015)

Atapattu "Justice for Small Island Nations"

Atapattu SA "Justice for Small Island Nations: Intersections of Equity, Human Rights, and Environmental Justice" in Abate RS (ed) Climate 
Justice: Case Studies in Global and Regional Governance Challenges (Environmental Law Institute Washington DC 2016) 299-322

Bodansky 2016 AJIL

Bodansky D "The Paris Climate Change Agreement: A New Hope?" 2016 AJIL 288-319

Bond Durban's Climate Gamble

Bond P (ed) Durban's Climate Gamble: Trading Carbon, Betting the Earth (Unisa Press Pretoria 2011)

Boyd et al 2009 Environ Sci Policy

Boyd E et al "Reforming the CDM for Sustainable Development: Lessons Learned and Policy Futures" 2009 Environ Sci Policy 820-831

Brown 2010 Ecology L Q

Brown ML "Limiting Corrupt Incentives in a Global REDD Regime" 2010 Ecology L Q 237-268

Burns "Human Rights Dimensions of Bioenergy"

Burns W "Human Rights Dimensions of Bioenergy with Carbon Capture and Storage: A Framework for Climate Justice in the Realm of Climate Geoengineering" in Abate RS (ed) Climate Justice: Case Studies in Global and Regional Governance Challenges (Environmental Law Institute Washington DC 2016) 149-170

Clémençon 2016 JED

Clémençon R "The Two Sides of the Paris Climate Agreement: Dismal Failure or Historic Breakthrough?" 2016 JED 3-24

Dahan et al 2016 Climate Brief

Dahan L et al "The Paris Agreement: A New International Framework to Facilitate the Uptake of Carbon Pricing" 2016 Climate Brief 1-8

Dehm 2016 JHRE

Dehm J "Indigenous Peoples and REDD+ Safeguards: Rights as Resistance or as Disciplinary Inclusion in the Green Economy?" 2016 JHRE $170-217$

Dong and Holm Olsen 2015 Climate Policy

Dong $Y$ and Holm Olsen $\mathrm{K}$ "Stakeholder Participation in CDM and New Climate Mitigation Mechanisms: China CDM Case Study" 2015 Climate Policy 171-188 
Eni-ibukun "Climate Justice"

Eni-ibukun T "Climate Justice: The Clean Development Mechanism as a Case Study" in Hollo E et al (eds) Climate Change and the Law (Springer New York 2013) 225-256

Felipe Perez et al 2016 LEAD

Felipe Perez B et al "Rethinking the Role of Development Banks in Climate Finance: Panama's Barro Blanco CDM Project and Human Rights" 2016 LEAD 1-17

Holm Olsen, Arens and Mersmann 2017 Climate Policy

Holm Olsen K, Arens C and Mersmann F "Learning from CDM SD Tool Experience for Article 6.4 of the Paris Agreement" 2017 Climate Policy 1-13

Humphreys Human Rights and Climate Change

Humphreys S Human Rights and Climate Change (Cambridge University Press Cambridge 2010)

Lütken and Michaelowa Corporate Strategies

Lütken $S$ and Michaelowa A Corporate Strategies and the Clean Development Mechanism (Edward Elgar Cheltenham 2008)

Marcu "Carbon Market Provisions"

Marcu A "Carbon Market Provisions in the Paris Agreement (Article 6)" 2016 CEPS Special Report 1-24

Mayer 2016 Climate Law

Mayer B "Human Rights in the Paris Agreement" 2016 Climate Law 109117

Michaelowa 2013 Climate Policy

Michaelowa A "A Call to Action: But too Late, in Vain?" 2013 Climate Policy 408-410

Michaelowa and Hoch 2016 CMR

Michaelowa A and Hoch S "How to Transition from the CDM to the Sustainable Development Mechanism under the Paris Agreement" 2016 CMR 28-31

Morten Haugen 2013 Nord Envtl L J

Morten Haugen $\mathrm{H}$ "What Role for Human Rights in Clean Development Mechanism, REDD+ and Green Climate Fund Projects?" 2013 Nord Envtl L J 51-70 
Nordic Trust Fund Human Rights Impact Assessments

Nordic Trust Fund Human Rights Impact Assessments: A Review of the Literature, Differences with other Forms of Assessments and Relevance for Development (World Bank Washington DC 2013)

Olawuyi "Fostering Accountability in Large-Scale"

Olawuyi DS "Fostering Accountability in Large-Scale Environmental Projects: Lessons from CDM and REDD+ Projects" in Wouters $\mathrm{J}$ et al (eds) Improving Delivery in Development: The Role of Voice, Social Contract and Accountability (World Bank Washington DC 2015) 129-147

Olawuyi 2016 JENRL

Olawuyi DS "Climate Justice and Corporate Responsibility: Taking Human Rights Seriously in Climate Actions and Projects" 2016 JENRL 27-44

Olawuyi Human Rights-Based Approach to Carbon Finance

Olawuyi DS The Human Rights-Based Approach to Carbon Finance (Cambridge University Press Cambridge 2016)

Olsen 2007 Climatic Change

Olsen K "The Clean Development Mechanism's Contribution to Sustainable Development: A Review of the Literature" 2007 Climatic Change 59-73

Quirico and Boumghar Climate Change and Human Rights Quirico $\mathrm{O}$ and Boumghar M Climate Change and Human Rights: An International and Comparative Law Perspective (Routledge London 2016)

Raeschke-Kessler 2016 CMR

Raeschke-Kessler K "How to Make Article 6. 4 of the Paris Agreement Work" 2016 CMR 8-11

Romanin Jacur "Promoting Investments in Sustainable Development" Romanin Jacur $F$ "Promoting Investments in Sustainable Development through Multilateral Environmental Agreements" in Treves T, Seatzu F and Trevisanut S (eds) Foreign Investment, International Law and Common Concerns (Routledge London 2014) 170-188

Savaresi 2016 JENRL

Savaresi A "The Paris Agreement: A New Beginning?" 2016 JENRL 16-26

Schade and Obergassel 2014 Camb Rev Int Aff

Schade $\mathrm{J}$ and Obergassel W "Human Rights and the Clean Development Mechanism" 2014 Camb Rev Int Aff 717-735 
Schatz 2008 GIELR

Schatz A "Discounting the Clean Development Mechanism" 2008 GIELR 704-742

Schneider 2009 Climate Policy

Schneider L "Assessing the Additionally of CDM Projects: Practical Experiences and Lessons Learned" 2009 Climate Policy 242-254

Sterk et al Further Development of the Project Based Mechanisms Sterk W et al Further Development of the Project Based Mechanisms in a Post-2012 Regime (Wuppertal Institute Wuppertal 2009)

Streck, Keenlyside and Von Unger 2016 JEEPL

Streck C, Keenlyside P and and Von Unger M "The Paris Agreement: A New Beginning" 2016 (13) JEEPL 3-29

Sutter and Parreño 2007 Climatic Change

Sutter C and Parreño JC "Does the Current Clean Development Mechanism (CDM) Deliver its Sustainable Development Claim? An Analysis of Officially Registered CDMPprojects" 2007 Climatic Change 75-90

Tarek et al 2007 Cornell Int'l L J

Tarek F et al"Extracting Corporate Responsibility: Towards a Human Rights Impact Assessment" 2007 Cornell Int'I L J 135-169

Turner Substantive Environmental Right

Turner S (ed) A Substantive Environmental Right. An Examination of the Legal Obligations of Decision-Makers towards the Environment (Kluwer Law International Alphen aan den Rijn 2008)

Voigt "Responsibility for the Environmental Integrity of the CDM"

Voigt C "Responsibility for the Environmental Integrity of the CDM: Judicial Review of Executive Board Decisions" in Freestone D and Streck C (eds) Legal Aspects of Carbon Trading: Kyoto, Copenhagen, and Beyond (Oxford University Press Oxford 2009) 272-294

Voigt "Deadlock of the Clean Development Mechanism"

Voigt C "The Deadlock of the Clean Development Mechanism: Caught between Sustainability, Environmental Integrity and Economic Efficiency" in Richardson B et al (eds) Climate Law and Developing Countries: Legal and Policy Challenges for the World Economy (Edward Elgar Cheltenham 2009) 235-261 
Wilson 2011 Ecology $L Q$

Wilson $\mathrm{K}$ "Access to Justice for Victims of the International Carbon Offset Industry" 2011 Ecology L Q 967-1032

\section{International instruments}

Decision 3/CMP.1 - Modalities and Procedures for a Clean Development Mechanism as Defined in Article 12 of the Kyoto Protocol UN Doc FCCC/KP/CMP/2005/8/Add.1 (2006)

Decision 1/CP.16 - Cancun Agreements UN Doc FCCC/CP/2010/7/Add.1 (2011)

Decision 1/CP.17 - Establishment of an Ad Hoc Working Group on the Durban Platform for Enhanced Action UN Doc FCCC /CP/2011/9/Add.1 (2012)

Decision 1/CP.19 - Further Advancing the Durban Platform UN Doc FCCC/CP/2013/10/Add.1 (2014)

Decision 1/CP.20 - Lima Call for Climate Action UN Doc FCCC/CP/2014/10/Add.1 (2015)

Decision 1/CP.21 - Adoption of the Paris Agreement UN Doc FCCC/CP/2015/10/Add.1 (2016)

Kyoto Protocol (1997)

Male' Declaration on the Human Dimension of Global Climate Change (2007)

Paris Agreement (2015)

Report of the Office of the United Nations High Commissioner for Human Rights on the Relationship between Climate Change and Human Rights UN Doc A/HRC/10/61 (2009)

Report of the Special Rapporteur on Extreme Poverty and Human Rights UN Doc A/HRC/23/36 (2013)

Report of the Special Rapporteur on the Issue of Human Rights Obligations Relating to the Enjoyment of a Safe, Clean, Healthy and Sustainable Environment UN Doc A/HRC/31/52 (2016) 
Resolution on Human Rights and Climate Change UNHRC Res 7/23, UN Doc A/HRC/7/78 (2008)

Resolution on Human Rights and Climate Change HRC Res 10/4, UN Doc A/HRC/10/4 (2009)

Resolution on Human Rights and Climate Change HRC Res 18/22, UN Doc A/HRC/18/22 (2011)

Resolution on Human Rights and Climate Change HRC Res 26/27, UN Doc A/HRC/26/27 (2014)

Resolution on Human Rights and Climate Change HRC Res 29/15, UN Doc A/HRC/RES/29/15 (2015)

Resolution on Human Rights and Climate Change HRC Res 32/33, UN Doc A/HRC/RES/32/33 (2016)

UN Declaration on the Rights of Indigenous Peoples Res 61/295, Annex, UN Doc A/RES/61/295 (2007)

United Nations Framework Convention on Climate Change (1992)

\section{Internet sources}

Arens et al 2015 http://orbit.dtu.dk/files/115264238/ Reforming_the_CDM_SD_Tool.pdf

Arens C et al 2015 Reforming the CDM SD Tool. Recommendations for Improvement http://orbit.dtu.dk/files/115264238/Reforming_the_CDM_SD _Tool.pdf accessed 10 June 2017

BankTrack 2016 https://www.banktrack.org/project/sasan_ultra_mega_ coal_power_project_umpp_/pdf

BankTrack 2016 Sasan Ultra Mega Coal Power Project (UMPP) India https://www.banktrack.org/project/sasan_ultra_mega_coal_power_project _umpp_/pdf accessed 28 November 2017

Bond et al 2012 http://www.ejolt.org/2012/12/the-cdm-cannot-deliver-themoney-to-africa-why-the-carbon-trading-gamble-won\%E2\%80\%99t-savethe-planet-from-climate-change-and-how-african-civil-society-is-resisting Bond P et al 2012 The CDM Cannot Deliver the Money to Africa. Why the Carbon Trading Gamble won't Save the Planet from Climate Change, and how African Civil Society is Resisting http://www.ejolt.org/2012/12/the-cdmcannot-deliver-the-money-to-africa-why-the-carbon-trading-gamble- 
won\%E2\%80\%99t-save-the-planet-from-climate-change-and-how-africancivil-society-is-resisting/ accessed 21 January 2018

Carbon Market Watch 2014 https://carbonmarketwatch.org/2014/04/14/ santa-rita-large-hydro-power-project-guatemala-2/

Carbon Market Watch 2014 "Santa Rita - Large Hydro Power Project, Guatemala" https://carbonmarketwatch.org/2014/04/14/santa-rita-largehydro-power-project-guatemala-2/ accessed 25 November 2017

Carbon Market Watch 2016 https://carbonmarketwatch.org/2011/07/04/ the-mandate-to-protect-human-rights-in-the-cdm-newsletter-17/

Carbon Market Watch 2016 The Mandate to Protect Human Rights in the CDM https://carbonmarketwatch.org/2011/07/04/the-mandate-to-protecthuman-rights-in-the-cdm-newsletter-17/ accessed 25 November 2017

CDM EB $2011 \mathrm{http} / / /$ unfccc.int/resource/docs/publications/cdm_annual _report_2011.pdf

CDM EB 2011 Annual Report: Clean Development Mechanism http://unfccc.int/resource/docs/publications/cdm_annual_report_2011.pdf accessed 12 June 2017

CDM EB 2012 http://www.kyomecha.org/document/CDM/EB70/ eb70annotation/eb70_Annex20_Draft_Tool_Sustainable_dev_cobenefits_description_for_CDM_project_activities_and_PoAs.pdf CDM EB 2012 Sustainable Development Co-benefits Description for CDM Project Activities and Programmes of Activities http://www.kyomecha.org/document/CDM/EB70/eb70annotation/eb70_An nex20_Draft_Tool_Sustainable_dev_co-benefits_description_for_CDM_ project_activities_and_PoAs.pdf accessed 15 June 2017

CDM EB 2013 http://cdm.unfccc.int/Reference/catalogue/document?doc id $=000003494$

CDM EB 2013 Procedure: Process for Dealing with Letters from DNAs that Withdraw Approval/Authorization http://cdm.unfccc.int/Reference/ catalogue/document?doc_id=000003494 accessed 23 May 2017

CDM $\quad$ EB $2015 \quad$ https://cdm.unfccc.int/filestorage/A/6/5/ A65DM07YFCU3JKIQRTZXOV1BGENPSL/eb87_meeting_report.pdf?t=Q 1h8b3hnbXI4fDBGYAy3HP7Xmlr_oyQ377mu

CDM EB 2015 Meeting Report: CDM Executive Board Eighty-seventh Meeting https://cdm.unfccc.int/filestorage/A/6/5/A65DM07YFCU3JKIQ RTZXOV1BGENPSL/eb87_meeting_report.pdf?t=Q1h8b3hnbXI4fDBGYA y3HP7Xmlr_oyQ377mu accessed 13 July 2017 
CDM EB 2015 https://cdm.unfccc.int/filestorage/5/2/C/52CZAHLKPTQ7 BE4GYOWV8INSJR9UF0/eb87_repan12.pdf?t=RFR8b3hnbHJOfDCwOJ_ 9zH_vbXyWVv-mUoJL

CDM EB 2015 Improving Stakeholder Consultation Processes https://cdm.unfccc.int/filestorage/5/2/C/52CZAHLKPTQ7BE4GYOWV8INS JR9UF0/eb87_repan12.pdf?t=RFR8b3hnbHJOfDCwOJ_9zH_vbXyWVvmUoJL accessed 14 July 2017

CDM Policy Dialogue 2012 http://www.cdmpolicydialogue.org/ CDM Policy Dialogue 2012 High-Level Panel on the CDM Policy Dialogue http://www.cdmpolicydialogue.org/ accessed 18 June 2017

CDM Policy Dialogue 2012 http://www.cdmpolicydialogue.org/ report/rpt110912.pdf

CDM Policy Dialogue 2012 Climate Change, Carbon Markets and the CDM: A Call to Action. Report of the High-Level Panel on the CDM Policy Dialogue http://www.cdmpolicydialogue.org/report/rpt110912.pdf accessed 18 June 2017

Environmental Justice Atlas 2014 https://ejatlas.org/conflict/kwale-okpaicdm-project-nigeria

Environmental Justice Atlas 2014 Kwale-Okpai CDM Project, Nigeria https://ejatlas.org/conflict/kwale-okpai-cdm-project-nigeria accessed 25 November 2017

FIDH et al $2011 \mathrm{https}: / /$ www.fidh.org/IMG/pdf/honduras573ang.pdf

FIDH et al 2011 Honduras: Human Rights Violations in Bajo Aguán https://www.fidh.org//MG/pdf/honduras573ang.pdf accessed 25 November 2017

Filzmoser et al 2015 http://orbit.dtu.dk/files/115264634/FILZMOSER.pdf Filzmoser E et al 2015 The Need for a Rights-Based Approach to the Clean Development Mechanism http://orbit.dtu.dk/files/ 115264634/FILZMOSER.pdf accessed 21 January 2018

Government of Brazil 2014 http://www4.unfccc.int/submissions/Lists/OSP SubmissionUpload/73_99_130602104651393682-BRAZIL\%20ADP\%20 Elements.pdf

Government of Brazil 2014 Views of Brazil on the Elements of the New Agreement under the Convention Applicable to all Parties http://www4.unfccc.int/submissions/Lists/OSPSubmissionUpload/73_99_1 30602104651393682-BRAZIL\%20ADP\%20Elements.pdf accessed 8 June 2017 
Haya and Parekh 2011 https://carbonmarketwatch.org/wpcontent/uploads/2011/11/Haya-Parekh-2011-Hydropower-in-the-CDM.pdf Haya B and Parekh P 2011 Hydropower in the CDM: Examining Additionality and Criteria for Sustainability https://carbonmarketwatch.org/wp-content/uploads/2011/11/Haya-Parekh2011-Hydropower-in-the-CDM.pdf accessed 8 June 2017

IACHR 2010 http://www.cidh.org/countryrep/Honduras10eng/Honduras10. Situation.htm

IACHR 2010 Preliminary Observations of the Inter-American Commission on Human Rights on Its Visit to Honduras http://www.cidh.org/countryrep/Honduras10eng/Honduras10.Situation.htm accessed 10 June 2017

Independent Expert 2014 http://www.ohchr.org/EN/Issues/Environment/ SREnvironment/Pages/ClimateChange.aspx

Independent Expert on Human Rights and the Environment 2014 Focus Report on Human Rights and Climate Change http://www.ohchr.org/EN/Issues/Environment/SREnvironment/Pages/Clim ateChange.aspx accessed 20 May 2017

Inuit Circumpolar Council 2005 http://www.inuitcircumpolar.com/inuitpetition-inter-american-commission-on-human-rights-to-oppose-climatechange-caused-by-the-united-states-of-america.html Inuit Circumpolar Council 2005 Inuit Petition to the Inter-American Commission on Human Rights to Oppose Climate Change Caused by United States of America http://www.inuitcircumpolar.com/inuit-petitioninter-american-commission-on-human-rights-to-oppose-climate-changecaused-by-the-united-states-of-america.html accessed 18 May 2017

Johl and Lador 2012 http://www.ciel.org/reports/a-human-rights-basedapproach-to-climate-finance-johl-lador-february-2012-3/

Johl A and Lador Y 2012 A Human Rights-based Approach to Climate Finance http://www.ciel.org/reports/a-human-rights-based-approach-toclimate-finance-johl-lador-february-2012-3/ accessed 30 November 2017

Mary Robinson Foundation 2015 http://www.mrfcj.org/resources/ statement-from-mary-robinson-on-the-paris-agreement/ Mary Robinson Foundation 2015 An Agreement for Humanity - Statement from Mary Robinson on the Paris Agreement 2015 https://www.mrfcj.org/resources/statement-from-mary-robinson-on-theparis-agreement/ accessed 15 January 2017 
NDC Registry 2017 http://www4.unfccc.int/ndcregistry/Pages/Home.aspx NDC Registry 2017 Welcome to the Interim NDC Registry http://www4.unfccc.int/ndcregistry/Pages/Home.aspx accessed 14 June 2017

OHCHR 2015 http://www.ohchr.org/EN/NewsEvents/Pages/DisplayNews. aspx?News $\mid \mathrm{D}=16836 \&$ Lang $\mid \mathrm{D}=\mathrm{E}$

OHCHR 2015 COP21: "States' Human Rights Obligations Encompass Climate Change" - UN Expert http://www.ohchr.org/EN/NewsEvents/ Pages/DisplayNews.aspx?NewsID=16836\&LangID=E accesses 5 March 2017

OHCHR 2015 http://www.ohchr.org/Documents/lssues/ClimateChange/ COP21.pdf

OHCHR 2015 Understanding Human Rights and Climate Change Submission of the Office of the High Commissioner for Human Rights (OHCHR) to the 21st Conference of the Parties to the United Nations Framework Convention on Climate Change http://www.ohchr.org/ Documents/Issues/ClimateChange/COP21.pdf accessed 15 March 2017.

UN 2014 http://www.ohchr.org/Documents/HRBodies/SP/SP_To_ UNFCCC.pdf

UN 2014 Open Letter from the Special Procedures Mandate-holders of the HRC to the State Parties to the UNFCCC on the Occasion of the Meeting of the Ad Hoc Working Group on the Durban Platform for Enhanced Action in Bonn - A New Climate Change Agreement must Include Human Rights Protection for All http://www.ohchr.org/Documents/HRBodies/SP/SP_To_ UNFCCC.pdf accessed 28 May 2017

UN Development Group 2013 http://www.ohchr.org/Documents/lssues/ MDGs/UNDGAMillionVoices.pdf

UN Development Group 2013 A Million Voices: The World We Want: A Sustainable Future with Dignity for All http://www.ohchr.org/ Documents/lssues/MDGs/UNDGAMillionVoices.pdf accessed 30 June 2015

UNFCCC $2011 \mathrm{https} / / /$ cdm.unfccc.int/about/dev_ben/index.html UNFCCC 2011 Benefits of the Clean Development Mechanism https://cdm.unfccc.int/about/dev_ben/index.html accessed 10 May 2017 
UNFCCC $2015 \mathrm{http} / / /$ unfccc.int/resource/docs/2015/cop21/eng/07.pdf UNFCCC 2015 Synthesis Report on the Aggregate Effect of Intended Nationally Determined Contributions (INDCs) http://unfccc.int/ resource/docs/2015/cop21/eng/07.pdf accessed 20 May 2017

UNFCC $2017 \mathrm{https}: / / \mathrm{cdm}$.unfccc.int/

UNFCC 2017 Clean Development Mechanism (CDM) https://cdm.unfccc.int/ accessed 18 March 2017

UNFCC 2017 https://cdm.unfccc.int/Statistics/Public/CDMinsights/ index.html

UNFCC 2017 Project Activities https://cdm.unfccc.int/Statistics/ Public/CDMinsights/index.html accessed 18 March 2017

UNFCC 2017 http://cdmcobenefits.unfccc.int

UNFCC 2017 Sustainable Development co-Benefits Tool http://cdmcobenefits.unfccc.int accessed 18 March 2017

Zagema 2011 https://www.oxfam.org/en/research/land-and-power Zagema B 2011 Land and Power: The Growing Scandal Surrounding the New Wave of Investments in Land https://www.oxfam.org/en/research/ land-and-power accessed 18 March 2017

\section{List of Abbreviations}
AJIL
American Journal of International Law
CA
Cancun Agreements
Camb Rev Int Aff
Cambridge Review of International Affairs
CDM
Clean Development Mechanism
CDM EB
Clean Development Mechanism - Executive
Board
CERs
Certified Emission Reductions
CMA
Conference of the Parties serving as the
CMR meeting of the Parties to the Paris Agreement
COP20
Carbon Mechanisms Review
COP21
$20^{\text {th }}$ Conference of the Parties to the UNFCCC
Cornell Int'I L J
$21^{\text {st }}$ Conference of the Parties to the UNFCCC
DOEs
EB
Cornell International Law Journal
Ecology $L Q$
Designated Operational Entities
Executive Board
EIA
Ecology Law Quarterly
Environmental Impact Assesment 


$\begin{array}{ll}\text { Environ Sci Policy } & \text { Environmental Science \& Policy } \\ \text { FIDH } & \text { International Federation for Human Rights } \\ \text { GHG } & \text { Greenhouse gases } \\ \text { GIELR } & \text { Georgetown International Environmental Law } \\ & \text { Review } \\ \text { HRC } & \text { Human Rights Council } \\ \text { HRIAs } & \text { Human rights impact assessments } \\ \text { IACHR } & \text { Inter-American Commission on Human Rights } \\ \text { Int Environ Agreem } & \text { International Environmental Agreements: } \\ & \text { Politics, Law and Economics } \\ \text { JED } & \text { Journal of Environment \& Development } \\ \text { JEEPL } & \text { Journal for European Environmental and } \\ & \text { Planning Law } \\ \text { JENRL } & \text { Journal of Energy and Natural Resources Law } \\ \text { JHRE } & \text { Journal of Human Rights and the Environment } \\ \text { JSDLP } & \text { Journal of Sustainable Development Law and } \\ & \text { Policy } \\ \text { KP } & \text { Kyoto Protocol } \\ \text { LEAD } & \text { Law, Environment and Development Journal } \\ \text { NDCs } & \text { Nationally Determined Contributions } \\ \text { Nord Envtl L J } & \text { Nordic Environmental Law Journal } \\ \text { OHCHR } & \text { Office of the High Commissioner for Human } \\ \text { PA } & \text { Rights } \\ \text { PDD } & \text { Paris Agreement } \\ \text { REDD+ } & \text { Project Design Document } \\ \text { SD tool } & \text { Reducing Emissions from Deforestation and } \\ \text { SDM } & \text { Forest Degradation } \\ \text { UN } & \text { Sustainable development tool } \\ \text { UNFCCC } & \text { Sustainable Development Mechanism } \\ & \text { United Nations } \\ \text { United Nations Framework Convention on } \\ \text { Climate Change }\end{array}$

